\title{
Special issue in memory of Nicholas Ambraseys
}

\author{
John Douglas • Atilla Ansal
}

Received: 26 December 2013 / Accepted: 27 December 2013 / Published online: 21 January 2014

C) Springer Science+Business Media Dordrecht 2014

Nicholas (Nick) Ambraseys was born in Athens (Greece) on 19th January 1929 and died peacefully at his home in Putney (London, United Kingdom) on 28th December 2012 at the age of 83. Nick attended the National Technical University of Athens, receiving his diploma in Rural Engineering in 1952. Following this and service in the Royal Hellenic Navy, he moved to Imperial College in London to study in the Soil Mechanics section of the Department of Civil Engineering for his Diploma of Imperial College and later his PhD, which he was awarded in 1958. Following a few years at universities in Greece and in the United States of America he returned to Imperial College and remained there until his death. He was made Professor of Engineering Seismology in 1974. In 1968 he established the Engineering Seismology section in the Department of Civil Engineering and from 1971 to 1994 he led this section. In 1994 he officially retired but he remained very active as an Emeritus Professor and his publications continued at an undiminished rate. Nick's contributions to engineering seismology and earthquake engineering were immense, wide-ranging and spanned almost 60 years.

Nick's research interests were varied and stretched from trying to better understand the earthquake source, through critical evaluation of historical documents and seismograms; via strong-motion studies seeking to improve predictions of shaking in future earthquakes for engineering purposes; to understanding and modelling the influence of this shaking on soil, buildings and populations. As he said in replying to the award of the Seismological Society of America's Reid Medal in 2006: 'the site of a damaging earthquake is a full-scale laboratory from which significant discoveries may be made, by seismologists, geologists, engineers, sociologists, or economists, not to mention politicians'.

In view of Nick's 'broadband' approach, the subjects covered by this special issue include: earthquake studies based on historical documents, improvements in instrumental catalogues, improvements to ground-motion prediction, use of strong-motion data to examine problems

\footnotetext{
J. Douglas $(\varangle)$

DRP/RSV, BRGM, 3 avenue C. Guillemin, 45060 Orleans Cedex, France

e-mail: J.Douglas@brgm.fr
}

A. Ansal

Ozyegin University, Istanbul, Turkey 
in structural engineering and, a subject particularly close to Nick's heart: field missions, which he passionately believed were invaluable to the education of anyone with an interest in earthquakes and their effects. The author list includes former students, friends and collaborators but also those who, although having never worked directly with Nick, have been inspired by his work. It includes authors from many countries spread over five continents (Europe, Asia, Australasia, Africa and North America), demonstrating Nick's global renown.

Nick's influence is demonstrated by the great number of obituaries and eulogies that have been published since his death at the end of 2012. These articles include those in international journals: Bulletin of Earthquake Engineering, Géotechnique, Journal of Earthquake Engineering, Journal of Seismology and Seismological Research Letters, newsletters of various learned societies: IASPEI, SECED, IAEE, International Society for Soil Mechanics and Geotechnical Engineering and EERI, and more mainstream publications: Times Higher Educational Supplement and the Imperial Magazine. In addition, various events have been held or are planned in his memory, including a special session at the Vienna Congress on Recent Advances in Earthquake Engineering and Structural Dynamics (2013) and a Memorial Symposium at the Royal Geographical Society (2014).

The opening article of this special issue is Nick's final journal article, which was submitted only a couple of months before his death. It concerns the contributions that the Ottoman archives can make to an improved understanding of the seismicity of the eastern Mediterranean region. Because the reviews of this article were received after Nick's death it has been accepted in its original form and it has not been revised.

A number of the articles, by authors who often worked with him, address studies of seismicity from the pre-instrumental age inspired by Nick's rigorous approach. These studies cover earthquakes from many parts of the world. Albini et al. (2014) present a detailed analysis of earthquakes occurring in the Eastern Cape Province of South Africa during the nineteenth and early twentieth centuries. Bilham and Bali (2014)'s study goes far back in time to ninth century Kashmir. McCue (2014) reminisces on Nick's influence on investigations of Australian earthquakes. Gordon Woo tells the poorly-known story of Nick's involvement in the seismic hazard assessments conducted for UK nuclear power plants in the early 1980s (Woo 2014). Hough (2014) presents a new approach for the processing of macroseismic intensities, one of the indicators of earthquakes that Nick often assessed and manipulated. Musson (2014) follows in Nick's footprints (e.g. Ambraseys and Adams 1986) by revisiting the seismicity of Ghana. Finally, Sigbjörnsson and Rupakhety (2014) re-examine the 1896 Icelandic earthquakes in terms of their magnitudes and effects.

Another one of Nick's topics of interest was the calculation of improved estimates of the earthquake magnitude. A contribution on this topic is provided by Gallo et al. (2014). Another string to Nick's bow was the use of strong-motion data to inform engineering analysis, e.g. through the development of ground-motion prediction equations. This aspect is covered in this issue by Boore and Goulet (2014), Lee and Green (2014) and Margaris et al. (2014). Elghazouli et al. (2014) provides an analysis of structural response under earthquake loading. Anyone who spent any period of time with Nick knew how much he valued field experience of earthquakes and how he was dismissive of 'armchair seismologists' (Ambraseys (1988)). This aspect of his legacy is discussed by Rossetto et al. (2014).

We would like to thank the peer reviewers of the articles of this special issue for their careful and timely comments on these studies. These reviews greatly helped improve the quality of these contributions. 


\section{References}

Albini P, Strasser FO, Flint NS (2014) Earthquakes from 1820 to 1936 in Grahamstown and surroundings (Eastern Cape Province, South Africa). Bull Earthquake Eng. doi:10.1007/s10518-013-9562-0

Ambraseys NN (1988) Engineering seismology: part II. Earthq Eng Struct Dyn 17(1):51-105

Ambraseys N, Adams R (1986) Seismicity of West Africa. Annales Geophys 6:679-702

Bilham R, Bali BS (2014) A ninth century earthquake-induced landslide and flood in the Kashmir Valley, and earthquake damage to Kashmir's medieval temples. Bull Earthquake Eng. doi:10.1007/s10518-013-9504-x

Boore DM, Goulet CA (2014) The effect of sampling rate and anti-aliasing filters on high-frequency response spectra. Bull Earthquake Eng. doi:10.1007/s10518-013-9574-9

Elghazouli AY, Kumar M, Stafford PJ (2014) Prediction and optimisation of seismic drift demands incorporating ground motion frequency content. Bull Earthquake Eng. doi:10.1007/s10518-013-9568-7

Gallo A, Costa G, Suhadolc P (2014) Near real-time automatic moment magnitude estimation. Bull Earthquake Eng. doi: $10.1007 / \mathrm{s} 10518-013-9565-\mathrm{X}$

Hough SE (2014) Earthquake intensity distributions: a new view. Bull Earthquake Eng. doi:10.1007/ s10518-013-9573-x

Lee J, Green RA (2014) An empirical significant duration relationship for stable continental regions. Bull Earthq Eng. doi:10.1007/s10518-013-9570-0

McCue K (2014) Making sense of Australian earthquakes: the Ambraseys legacy. Bull Earthquake Eng. doi:10. 1007/s10518-013-9524-6

Margaris B, Kalogeras I, Papaioannou C, Savvaidis A, Theodoulidis N (2014) Notes for the evaluation of a national strong motion network in Greece: planning, deployment, data-processing and site characterization. Bull Earthquake Eng. doi:10.1007/s10518-013-9580-y

Musson RMW (2014) The seismicity of Ghana. Bull Earthquake Eng. doi:10.1007/s10518-013-9555-z

Rossetto T, D'Ayala D, Gori F, Persio R, Han J, Novelli V, Wilkinson SM, Alexander D, Hill M, Stephens S, Kontoe S, Elia G, Verrucci E, Vicini A, Shelley W, Foulser-Piggott R (2014) The value of multiple earthquake missions: the EEFIT L'Aquila earthquake experience. Bull Earthquake Eng. doi:10.1007/ s10518-014-9588-y

Sigbjörnsson R, Rupakhety R (2014) A saga of the 1896 south Iceland earthquake sequence: magnitudes, macroseismic effects and damage. Bull Earthquake Eng. doi:10.1007/s10518-013-9579-4

Woo G (2014) Historical development of the British and Scandinavian earthquake archives. Bull Earthquake Eng. doi:10.1007/s10518-013-9487-7 